\title{
Resumption of Smoking by Women after Childbirth: Influence of Spousal Smoking
}

\author{
Atsuko Satoh ${ }^{*}$, Chikako Kishi' ${ }^{2}$, Megumi Tomita1, Masumi Saitoh', Miwako Hirakawa1, \\ Miki Kumasaka1, Jinich Sasaki' ${ }^{1}$, Sangun Lee ${ }^{3}$, Hidetada Sasaki ${ }^{4}$ \\ ${ }^{1}$ Department of Nursing, Hirosaki University of Health and Welfare, Aomori, Japan \\ ${ }^{2}$ Kensei Hospital, Aomori, Japan \\ ${ }^{3}$ Department of Physical Therapy, Aomori University of Health and Welfare, Aomori, Japan \\ ${ }^{4}$ Sendai Tomizawa Hospital, Sendai, Japan \\ Email: *a-satoh@jyoto-gakuen.ac.jp
}

Received 3 May 2016; accepted 12 June 2016; published 15 June 2016

Copyright (C) 2016 by authors and Scientific Research Publishing Inc.

This work is licensed under the Creative Commons Attribution International License (CC BY).

http://creativecommons.org/licenses/by/4.0/

cC) (7) Open Access

\begin{abstract}
To investigate factors related to resumption of smoking by women after childbirth, the smoking habits of 241 postnatal women, who initially had stopped smoking after pregnancy, in a rural city in Aomori Prefecture, Japan, were studied at 5 - 6 days, 1 month, and 12 months after childbirth. At 1 month after childbirth, only nine women had resumed smoking, but a total of 40 women had resumed smoking after 12 months. Factors related to smoking resumption after childbirth included the switching from breast feeding to bottle feeding and the influence of smoking by their spouses. Spousal smoking is an important factor in the resumption of smoking by women after childbirth.
\end{abstract}

\section{Keywords}

Bottle Feeding, Breast Feeding, Spousal Smoking, Postnatal, Smoking

\section{Introduction}

Many smokers are unable or unwilling to give up smoking despite the fact that it is linked with serious respiratory diseases [1]. Smoking habits may be influenced by mental disorders, including anxiety and depression [2], increased actual or perceived stress [3], and abuse-related post-traumatic stress disorders [4].

The prevalence of postpartum depression and its devastating consequences for the mother imply that postpartum depression has a significant public impact. In a previous study, we suggested that although smoking resumption may help alleviate postpartum depression, it can still have serious health consequences for women after childbirth [5]. Although most women quit smoking after pregnancy, one-third of women resumed smoking

${ }^{*}$ Corresponding author.

How to cite this paper: Satoh, A., Kishi, C., Tomita, M., Saitoh, M., Hirakawa, M., Kumasaka, M., Sasaki, J., Lee, S. and Sasaki, H. (2016) Resumption of Smoking by Women after Childbirth: Influence of Spousal Smoking. Health, 8, 813-817. 
within 1 year of childbirth [5].

In the present study, we investigated factors related to smoking resumption in women after childbirth.

\section{Methods}

Among 1051 postnatal women we adopted 250 postnatal women who were smoking before pregnancy but who ceased smoking after pregnancy. The setting was a rural city in Aomori Prefecture, northern Japan, (population, 174,000; number of births from April 2009 to January 2013, 4735) where mothers brought their infants for a check-up 5 - 6 days after delivery at six different obstetrics clinics.

Mothers who agreed to participate in the study completed self-reported questionnaires. Among the 250 invited women, 241 completed the questionnaires at 5 - 6 days after childbirth, and these women were prospectively followed up at 1 and 12 months. To ascertain the sociopsychological state of the participants, four questionnaires dealing with different aspects were provided, containing the following questions: Questionnaire 1, social status (age, educational level, and annual income); Questionnaire 2, obstetric factors [previous childbirth experience (i.e., primipara or multipara), premature birth and/or abortion, baby's weight at delivery, and breast feeding or bottle feeding]; Questionnaire 3, physical status (worries concerning baby care, alcohol consumption, smoking habit, and smoking habit of spouse); and Questionnaire 4, sociability, good relationship with spouse, satisfaction with childcare, and financial concerns.

The study protocol adhered to the recommendations of the Declaration of Helsinki [6]. Verbal informed consent was obtained, and the participants' anonymity was preserved using a coding system. Ethical approval was obtained from the Ethical Committee of Hirosaki University of Health and Welfare, Japan. The statistical differences of the sociopsychological states between the women who quit and resumed smoking after childbirth were calculated using the Chi-squared test. The differences were regarded as statistically significant at $p<0.05$.

\section{Results}

Among the 241 women who answered self-reported questionnaires 5 - 6 days after childbirth, 210 and 146 could be followed up at 1 and 12 months, respectively. At the 1-month follow-up, nine women had resumed smoking. Over the following period and up to 12 months, the total number of women who changed their smoking status from "quit smoking” to "resume smoking” was 40 (Table 1).

Smoking habits of spouses, alcohol intakes of the women, switch from breast feeding to bottle feeding, primiparas, and experience of abortion were significant factors influencing the sociopsychological state between those who quit smoking and those who resumed smoking (Table 1).

Multivariate regression analysis was used to compare smoking versus sociopsychological state at 12 months after childbirth. In the analyses, smoking by spouses, primiparas or multiparas, experience of abortion, alcohol intake, and breast feeding or bottle feeding corresponded to "yes" or "no" answers or choices " 1 " or " 2 ", respectively.

As shown in Table 2, the standardized multivariate regression coefficients of smoking by spouses, alcohol intake by women, switch from breast to bottle feeding, childbirth experience, and experience of abortion were $0.228(p=0.003), 0.188(p=0.013),-0.290(p=0.000),-0.098(p=0.203)$, and $0.122(p=0.112)$, respectively $\left(\mathrm{R}^{2}=0.22\right)$.

\section{Discussion}

There are many factors to affect the smoking resumption. Cessation of smoking will lead to a period of increased stress, followed by a return to baseline, because acute nicotine deprivation (i.e. between cigarettes) is stressful. Then, the former smoker no longer suffers from the adverse mood effects of acute nicotine depletion. However, it has not been established whether or not quitting smoking leads to reduced stress or not in terms of sociopsychological status of individual; for example, a person experiencing a stressful sociopsychological state smokers might not reduce stress level even after long-term cessation of smoking. Thus, it has been reported that as compared to non-smokers of mothers, smokers of mothers who had exhibited a more stressful sociopsychological state (higher levels of perceived stress, depression, neuroticism, and negative paternal support) were associated with rate of being a smoker than a non-smoker [7]. Work style (i.e. shift work) was critically associated with cigarette smoking in Japanese female workers [8]. 
Table 1. Factors of resumed smoking after childbirth.

\begin{tabular}{|c|c|c|c|c|c|c|c|c|}
\hline & & \multirow[t]{2}{*}{5 - 6 days after child birth } & \multicolumn{3}{|c|}{1 month after childbirth } & \multicolumn{3}{|c|}{12 months after childbirth } \\
\hline & & & $\begin{array}{c}\text { Quit } \\
\text { smokers }\end{array}$ & $\begin{array}{l}\text { Resumed } \\
\text { smokers }\end{array}$ & & $\begin{array}{c}\text { Quit } \\
\text { smokers }\end{array}$ & $\begin{array}{l}\text { Resumed } \\
\text { smokers }\end{array}$ & \\
\hline & & $\mathrm{n}=241$ & $\mathrm{n}=201$ & $\mathrm{n}=9$ & $p$ value & $\mathrm{n}=106$ & $\mathrm{n}=40$ & $p$ value \\
\hline Age & $\begin{array}{c}>10 \\
29-20 \\
45-30\end{array}$ & $\begin{array}{c}5 \\
140 \\
96\end{array}$ & $\begin{array}{c}2 \\
121 \\
78\end{array}$ & $\begin{array}{l}0 \\
7 \\
2\end{array}$ & - & $\begin{array}{c}1 \\
46 \\
59\end{array}$ & $\begin{array}{c}0 \\
24 \\
16\end{array}$ & - \\
\hline Education & $\begin{array}{l}\text { High school } \\
\text { University }\end{array}$ & $\begin{array}{l}140 \\
101\end{array}$ & $\begin{array}{c}111 \\
90\end{array}$ & $\begin{array}{l}6 \\
3\end{array}$ & NS & $\begin{array}{l}46 \\
56\end{array}$ & $\begin{array}{l}18 \\
18\end{array}$ & NS \\
\hline $\begin{array}{l}\text { Annual income } \\
\text { (million yen) }\end{array}$ & $\begin{array}{l}<300 \\
301- \\
500-\end{array}$ & $\begin{array}{c}85 \\
110 \\
46\end{array}$ & $\begin{array}{l}73 \\
88 \\
40\end{array}$ & $\begin{array}{l}2 \\
3 \\
4\end{array}$ & NS & $\begin{array}{l}32 \\
47 \\
24\end{array}$ & $\begin{array}{c}13 \\
18 \\
8\end{array}$ & NS \\
\hline $\begin{array}{l}\text { Frequency } \\
\text { of delivery }\end{array}$ & $\begin{array}{l}\text { Primiparas } \\
\text { Multiparas }\end{array}$ & $\begin{array}{l}135 \\
106\end{array}$ & $\begin{array}{c}110 \\
91\end{array}$ & $\begin{array}{l}6 \\
3\end{array}$ & NS & $\begin{array}{l}65 \\
41\end{array}$ & $\begin{array}{l}17 \\
33\end{array}$ & $* * *$ \\
\hline $\begin{array}{l}\text { Experience } \\
\text { of abortion }\end{array}$ & $\begin{array}{l}\text { Yes } \\
\text { No }\end{array}$ & $\begin{array}{c}99 \\
142\end{array}$ & $\begin{array}{c}86 \\
115\end{array}$ & $\begin{array}{l}2 \\
7\end{array}$ & NS & $\begin{array}{l}42 \\
64\end{array}$ & $\begin{array}{l}25 \\
15\end{array}$ & * \\
\hline Birth weight & $\begin{array}{l}<2500 \\
\geq 2500\end{array}$ & $\begin{array}{c}22 \\
219\end{array}$ & $\begin{array}{c}19 \\
182\end{array}$ & $\begin{array}{l}1 \\
8\end{array}$ & NS & $\begin{array}{l}11 \\
95\end{array}$ & $\begin{array}{c}4 \\
36\end{array}$ & NS \\
\hline Spousal smoking & $\begin{array}{l}\text { Yes } \\
\text { No }\end{array}$ & $\begin{array}{c}196 \\
45\end{array}$ & $\begin{array}{c}157 \\
43\end{array}$ & $\begin{array}{l}8 \\
1\end{array}$ & NS & $\begin{array}{l}71 \\
35\end{array}$ & $\begin{array}{c}37 \\
3\end{array}$ & $* * *$ \\
\hline $\begin{array}{l}\text { Alcohol consumption } \\
\text { by women }\end{array}$ & $\begin{array}{l}\text { Yes } \\
\text { No }\end{array}$ & $\begin{array}{c}0 \\
241\end{array}$ & $\begin{array}{c}15 \\
178\end{array}$ & $\begin{array}{l}3 \\
6\end{array}$ & * & $\begin{array}{l}43 \\
63\end{array}$ & $\begin{array}{l}26 \\
14\end{array}$ & $* * *$ \\
\hline Feeding & $\begin{array}{l}\text { Breast feeding } \\
\text { Bottle feeding }\end{array}$ & $\begin{array}{c}234 \\
7\end{array}$ & $\begin{array}{c}131 \\
63\end{array}$ & $\begin{array}{l}2 \\
7\end{array}$ & $* *$ & $\begin{array}{l}82 \\
21\end{array}$ & $\begin{array}{l}17 \\
23\end{array}$ & $* * *$ \\
\hline $\begin{array}{l}\text { Worries about } \\
\text { baby care }\end{array}$ & $\begin{array}{l}\text { Yes } \\
\text { No }\end{array}$ & $\begin{array}{c}53 \\
188\end{array}$ & $\begin{array}{c}33 \\
164\end{array}$ & $\begin{array}{l}3 \\
6\end{array}$ & NS & $\begin{array}{l}10 \\
95\end{array}$ & $\begin{array}{c}7 \\
33\end{array}$ & NS \\
\hline
\end{tabular}

Table 2. Multivariable model of the relationship between quit smokers and resumed smokers at 12 month after childbirth.

\begin{tabular}{ccc}
\hline Risk variable & Regression coefficient & $p$ value \\
\hline Spousal smoking & 0.228 & 0.003 \\
Alcohol consumption by women & 0.188 & 0.013 \\
Feeding & -0.290 & 0.000 \\
Frequency of delivery & -0.098 & 0.203 \\
Experience of abortion & 0.122 & 0.112 \\
\hline
\end{tabular}

Multiple correlation coefficient $=0.497$, Adjusted $\mathrm{R}^{2}=0.220$.

In the present study, we observed that switching from breast feeding to bottle feeding and spousal smoking was important triggers for women who resumed smoking. Alcohol intake by women was also significant, although their significance was low, which is a serious challenge [9] [10]. In mothers, resumption of smoking was associated with a switch from breast feeding to bottle feeding, which suggested that smoking offers a means of relaxation from the stress of caring, feeding, and not being able to go outside the house [11]-[13]. Mothers who smoked did not tend to socialize. Spousal smoking increased the woman's temptation to smoke; therefore, if the spouse could quit smoking, women would be more successful in giving up smoking themselves.

Spousal support during and after pregnancy is suggested as an important factor in smoking cessation [14] [15]. In the present study, we observed that the presence or absence of spousal smoking was important in determining whether women had a higher probability of returning to smoking after childbirth. Reducing stress associated with caring for the baby may also allow mothers to avoid smoking because when the husband is closely involved in baby care, stress scores have been reported to be lower for women [16]-[18]. 
Alcohol consumption by mothers is also correlated (albeit weakly) with resumption of smoking; therefore, avoiding alcohol consumption may also help in their smoking cessation [19] [20]. Resumed smoking of women could not be simply prohibited unless other habits like alcohol and smoking habit of husbands are being fully cooperated. One potential limitation of the present study is that the number of participants sequentially decreased over the study period; this may have affected our results.

\section{Acknowledgements}

This work was supported by a grant from the Smoking Research Foundation and a grant for designated research provided by the President of Hirosaki University of Health and Welfare.

\section{Conflicts of Interest}

We declare no conflicts of interest.

\section{References}

[1] Sieminska, A. and Jassem, E. (2014) The Many Faces of Tobacco Use among Women. Medical Science Monitor: International Medical Journal of Experimental and Clinical Research, 20, 153-162. http://dx.doi.org/10.12659/MSM.889796

[2] Park, E.R., Chang, Y., Quinn, V., Regan, S., Cohen, L., Viguera, A. and Rigotti, N. (2009) The Association of Depressive, Anxiety, and Stress Symptoms and Postpartum Relapse to Smoking: A Longitudinal Study. Nicotine and Tobacco Research, 11, 707-714. http://dx.doi.org/10.1093/ntr/ntp053

[3] Lynch, M.E., Johnson, K.C., Kable, J.A., Carroll, J. and Coles, C.D. (2011) Smoking in Pregnancy and Parenting Stress: Maternal Psychological Symptoms and Socioeconomic Status as Potential Mediating Variables. Nicotine and Tobacco Research, 13, 532-539. http://dx.doi.org/10.1093/ntr/ntr037

[4] Lopez, W.D., Konrath, S.H. and Seng, J.S. (2011) Abuse-Related Post-Traumatic Stress, Coping, and Tobacco Use in Pregnancy. Journal of Obstetric, Gynecologic, and Neonatal Nursing, 40, 422-431. http://dx.doi.org/10.1111/j.1552-6909.2011.01261.x

[5] Satoh, A., Kitamiya, C., Yaegashi, Y., Ohse, F., Lee, S., Kishi, C. and Sasaki, H. (2013) Influence of Smoking on Postpartum Depression in Japan. Health, 8, 1254-1260. http://dx.doi.org/10.4236/health.2013.58170

[6] World Medical Association (2001) The International Response to Helsinki: The WMA's Declaration of Helsinki on Ethical Principles for Medical Research Involving Human Subjects. 52nd WMA General Assembly, Edinburgh, October 2000.

[7] Maxson, P.J., Edwards, S.E., Ingram, A. and Miranda, M.L. (2012) Psychosocial Differences between Smokers and Non-Smokers during Pregnancy. Addictive Behaviors, 37, 153-159. http://dx.doi.org/10.1016/j.addbeh.2011.08.011

[8] Miyatake, N., Nishii, K. and Numata, T. (2011) Relationship between Work Style and Cigarette Smoking in Japanese Workers. Health, 3, 537-541. http://dx.doi.org/10.4236/health.2011.39090

[9] Harmer, C. and Memon, A. (2013) Factors Associated with Smoking Relapse in the Postpartum Period: An Analysis of the Child Health Surveillance System Data in Southeast England. Nicotine and Tobacco Research, 15, 904-909. http://dx.doi.org/10.1093/ntr/nts221

[10] Neuman, A., Hohmann, C., Orsini, N., Pershagen, G., Eller, E., Kjear, H.F. and Bergstom, A. (2012) ENRIECO Consortium. Maternal Smoking in Pregnancy and Asthma in Preschool Children: A Pooled Analysis of Eight Cohorts. American Journal Respiratory Critical Care Medicine, 186, 1037-1043. http://dx.doi.org/10.1164/rccm.201203-05010C

[11] Gilbert, N.L., Nelson, C.R. and Greaves, L. (2015) Smoking Cessation during Pregnancy and Relapse after Childbirth in Canada. Journal of Obstetrics Gynecology Canada, 37, 32-39. http://dx.doi.org/10.1016/S1701-2163(15)30360-1

[12] Higgins, T.M., Hggins, S.T., Basger, G.J., Skelly, J.M., Bernstein, I.M. and Preston, A.M. (2010) Effect of Cigarette Smoking Cessation on Breastfeeding Duration. Nicotine and Tobacco Research, 12, 483-488. http://dx.doi.org/10.1093/ntr/ntq031

[13] Kendzor, D.E., Businelle, M.S., Costello, T.J., Castro, Y., Reitzel, L.R., Vidrine, J.I. and Wetter, D.W. (2010) Breast Feeding Is Associated with Postpartum Smoking Abstinence among Women Who Quit Smoking Due to Pregnancy. Nicotine and Tobacco Research, 12, 983-988. http://dx.doi.org/10.1093/ntr/ntq132

[14] Hemsing, N., Greaves, L., O’Leary, R., Chan, K. and Okoli, C. (2011) Partner Support for Smoking Cessation during Pregnancy: A Systematic Review. Nicotine and Tobacco Research, 14, 767-776. http://dx.doi.org/10.1093/ntr/ntr278

[15] Pollak, K.I., Baucom, D.H., Peterson, B.L., Stanton, S. and McBride, C.M. (2006) Rated Helpfulness and Partner-Re- 
ported Smoking Cessation Support across the Pregnancy-Postpartum Continuum. Health Psychology, 25, 762-770. http://dx.doi.org/10.1037/0278-6133.25.6.762

[16] Meghea, C.I., Brinzaniuc, A., Mihu, D., Iuhas, C.I., Stamatian, F., Caracostea, G. and Chereches, R.M. (2015) A Couple-Focused Intervention to Prevent Postnatal Smoking Relapse: PRISM Study Design. Contemporary Clinical Trials, 9, 273-279. http://dx.doi.org/10.1016/j.cct.2015.02.002

[17] Pollak, K.I., Fish, L.J., Lyna, P., Peterson, B.L., Swamy, G.K. and Levine, M.D. (2014) Predictors of Pregnant Quitters' Intention to Return to Smoking Postpartum. Nicotine and Tobacco Research, 26, 742-745.

[18] Satoh, A., Kitamiya, C., Kudoh, H., Watanabe, M., Menzawa, K. and Sasaki, H. (2009) Factors Associated with Late Post-Partum Depression in Japan. Japan Journal of Nursing Science, 6, 27-36. http://dx.doi.org/10.1111/j.1742-7924.2009.00121.x

[19] Parackal, S., Ferguson, E. and Harraway, J. (2007) Alcohol and Tobacco Consumption among 6-24 Months Post-Partum New Zealand Women. Maternal \& Child Nutrition, 3, 40-51. http://dx.doi.org/10.1111/j.1740-8709.2007.00064.x

[20] Wiesbeck, G.A., Kuhl, H.C., Yaldizli, O. and Wurst, F.M. (2008) Tobacco Smoking and Depression-Results from the WHO/ISBRA Study. Neuropsychobiology, 57, 26-31. http://dx.doi.org/10.1159/000123119 